\title{
RADIOCARBON DATING TEPHRA LAYERS IN BRITAIN AND ICELAND
}

\author{
A. J. DUGMORE, ${ }^{1}$ G. T. COOK, ${ }^{2}$ J. S. SHORE, ${ }^{2}$ A. J. NEWTON, ${ }^{1}$ K. J. EDWARDS ${ }^{3}$ \\ and GUĐRÚN LARSEN ${ }^{4}$
}

\begin{abstract}
Layers of volcanic ash, or tephra form widespread chronostratigraphic marker horizons which are important because of their distinctive characteristics and rapid deposition over large areas. Absolute dating of prehistoric layers effectively depends upon ${ }^{14} \mathrm{C}$ analysis. We focus here on Icelandic tephra layers at both proximal and distal sites and consider three strategies to obtain age estimates: 1) the conventional dating of individual profiles; 2) high-precision multisample techniques or "wiggle-matching" using stratigraphic sequences of peat; and 3) a combination of routine analyses from multiple sites. The first approach is illustrated by the dating of a peat profile in Scotland containing tephra from the AD 1510 eruption of Hekla. This produced a ${ }^{14} \mathrm{C}$ age compatible with $\mathrm{AD} 1510$, independently derived by geochemical correlation with historically dated Icelandic deposits. In addition, the $c a .2100$ BP date for the Glen Garry tephra in Scotland, determined by a series of dates on a peat profile in Caithness, is supported by its stratigraphic position within ${ }^{14} \mathrm{C}$ dated profiles in Sutherland, and may be applied over a very large area of Scotland. More precise dates for individual tephras may be produced by "wiggle-matching", although this approach could be biased by changes in peat-bog stratigraphy close to the position of the tephra fall. As appropriate sites for "wiggle-match" exercises may be found only for a few Icelandic tephras, we also consider the results of a spatial approach to ${ }^{14} \mathrm{C}$ dating tephra layers. We combined dates on peat underlying the same layer at several sites to estimate the age of the tephra: $3826 \pm 12$ BP for the Hekla-4 tephra and $2879 \pm 34 \mathrm{BP}$ for the Hekla-3 tephra. This approach is effective in terms of cost, the need for widespread applicability to Icelandic tephra stratigraphy and the production of ages of a useful resolution. We stress the need for accurate identification of tephra deposits without which the conclusions drawn from subsequent ${ }^{14} \mathrm{C}$ dating will be fundamentally flawed.
\end{abstract}

\section{INTRODUCTION}

Layers of volcanic ash, or tephra, form chronostratigraphic marker horizons of great importance because of their distinctive characteristics, widespread distribution and rapid dispersal. Tephra can be used to define time-parallel marker horizons, or isochrones, particularly valuable in paleoenvironmental studies because deposits at different sites may be correlated with a relative dating precision of years, months or even days (Thórarinsson 1981; Hallsdóttir 1987; Blackford et al. 1992; Merkt et al. 1993; Edwards et al. 1994). Within the historical period, reference to reliable records can provide calendar dates of similar precision (Thórarinsson 1967). In Iceland, since the 16th century, accurate records have been kept, from which dates of eruptions may be determined. Data becomes scarce between the mid-16th century and $\mathrm{AD}$ 1430, somewhat uneven for the preceding period of early annals writing and very poor for the centuries immediately following the 9th century Norse settlement (Thórarinsson 1967; Larsen 1984; Ogilvie 1984). If historical records are unavailable to date tephra layers, other techniques such as ${ }^{14} \mathrm{C}$ dating must be employed to estimate the "absolute" age (Kjartansson, Thórarinsson and Einarsson 1964). Where the surface onto which tephra has fallen can be identified, relative dating by reference to the stratigraphic marker formed by the tephra layer may still be precise to days or months, but the quality of an "absolute" age estimate will be determined by the characteristics of the method used. The chronological precision, however, can be optimized by using the best samples from within the area covered by the tephra. Further, the dating uncertainty associated with tephras in southern Iceland can be constrained by their positions in the detailed tephra stratigraphy of the region (Thórarinsson 1967; Larsen 1984; Dugmore 1989). For the Holocene, ${ }^{14} \mathrm{C}$ dating offers the most potential for dating tephra isochrones of unknown age. We consider here several alternative but complementary strategies.

\footnotetext{
${ }^{1}$ Department of Geography, University of Edinburgh, Edinburgh, EH8 9XP, Scotland

${ }^{2}$ Scottish Universities Research and Reactor Centre, Scottish Enterprise Technology Park, East Kilbride, G75 0QF, Scotland

${ }^{3}$ Department of Archaeology and Pre-History, University of Sheffield, Sheffield, S10 2TN, England

${ }^{4}$ Science Institute, University of Iceland, Reykjavík, IS-101 Iceland
} 


\section{Determining the "Absolute" Age of a Tephra Isochrone}

\section{Conventional Dating of a Single Stratigraphic Section}

A widely used strategy for dating tephra deposits is to ${ }^{14} \mathrm{C}$ date a vertical sequence at a single site (e.g., Björk et al. 1992; Bennett et al. 1992). The age of the tephra can be estimated from dates on the organic material coincident with or underlying the deposit, supported by the overall age/depth profile. We dated a shallow peat profile containing a zone of tephra (Fig. 1) at Loch Portain in the Scottish Outer Hebrides. The calibrated age/depth profile produced a range of possible ages for the tephra, but geochemical analysis identified two distinct populations of tephra, one of which can be correlated to Icelandic deposits from the $\mathrm{AD} 1510$ eruption of Hekla (Fig. 2; Dugmore, Larsen and Newton 1995). Historical records firmly place the start of this eruption on 25 July, and as the tephra that fell in Scotland is the silicic portion produced at the beginning of the eruption, it was probably deposited no later than 26 July, 485 yr ago (Thórarinsson 1967). Although a very precise age may be attributed to one of the tephra populations, this precision cannot be applied to a clearly defined level within the stratigraphy because the tephra horizon is diffuse. Taking the probable maximum and minimum rates of accumulation based on the ${ }^{14} \mathrm{C}$ ages, the tephra could be spread through material 125-195 yr old.

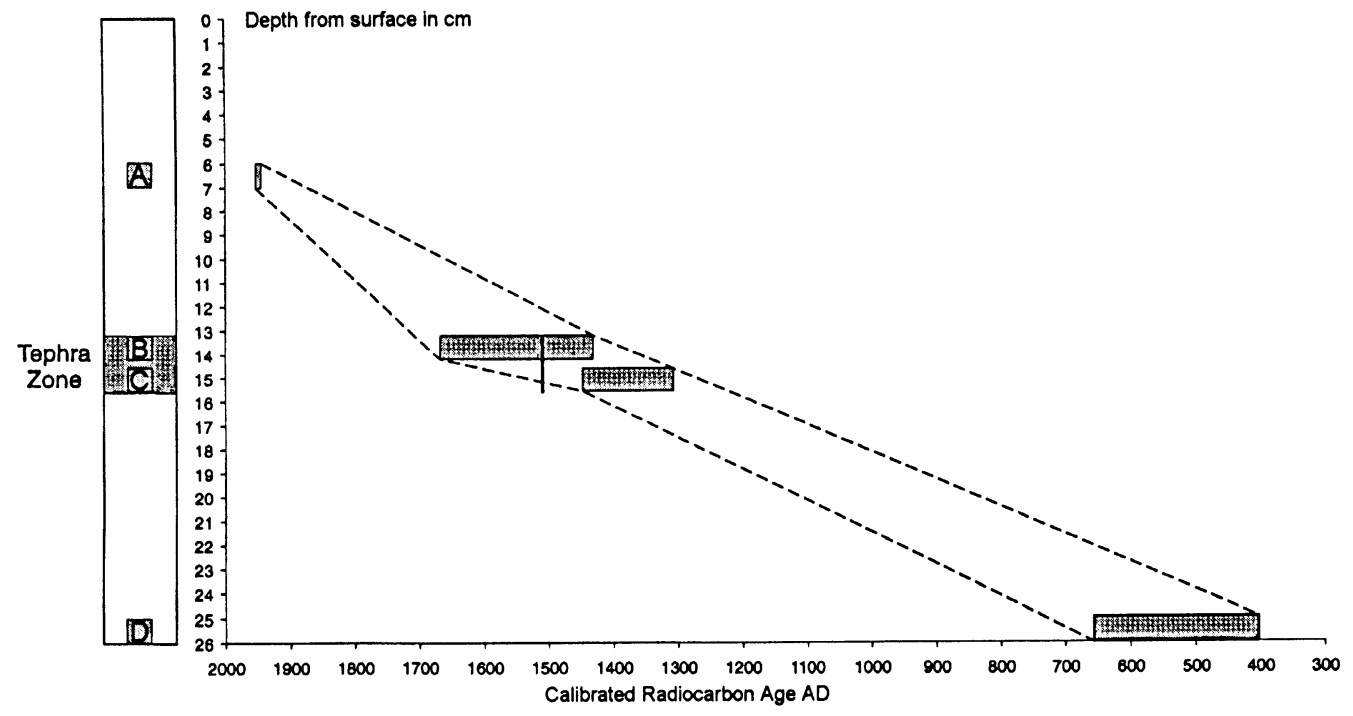

Fig. 1. A ${ }^{14} \mathrm{C}$-dated profile from Loch Portain, North Uist, Outer Hebrides, Scotland (NGR 950724). The stratigraphic location of four ${ }^{14} \mathrm{C}$ dates and a zone containing a diffuse horizon of very fine-grained tephra is shown in the left column. The date A. Modern; B. $360 \pm 70$ BP (GU-3010); C. $540 \pm 50$ BP (GU-3009); D. $1530 \pm 70$ BP (GU-3008). $=$ calibrated ${ }^{14} \mathrm{C}$ ages at $2 \sigma ;---=$ an envelope containing the likely age-depth profile (Stuiver and Reimer 1993). The tephra zone is formed by two distinct populations, one of which is geochemically correlated with Icelandic tephra from the $\mathrm{AD} 1510$ eruption of Hekla ( $c f$. Fig. 2). The vertical bar represents the independently derived calendar date, and is consistent with the calibrated ${ }^{14} \mathrm{C}$ ages.

A calendar date of $\mathrm{AD} 1510$ for a component of the tephra zone is compatible with the ${ }^{14} \mathrm{C}$ age/depth profile, but the 350 -yr range for the calibrated ${ }^{14} \mathrm{C}$ ages for the tephra zone, is significantly greater than the relative dating precision of the tephra defined by its stratigraphic position. There is clearly room to improve ${ }^{14} \mathrm{C}$ dating to match more closely the relative dating precision possible with distal tephra deposits. 


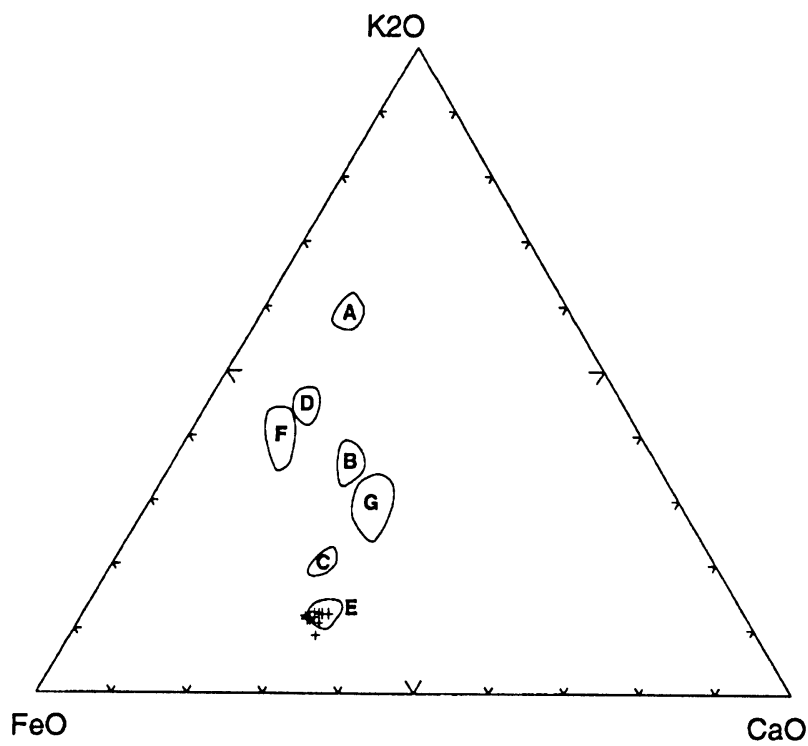

Fig. 2. The geochemical characteristics of seven silicic tephras produced by Icelandic volcanic eruptions in historical times. The fields are defined by data from the electron probe microanalysis of individual grains within tephra layers in Iceland. Analyses were carried out using a Cambridge Instruments Microscan V electron probe. We used a standard Wavelength Dispersive Spectrometry (WDS) method with an accelerating voltage of $20 \mathrm{KV}$ and a beam current of $15 \mathrm{nA}$. Other operating conditions are described elsewhere (Dugmore et al. 1992). A. Landnám tephra of ca. AD 900; B. Hekla AD 1104 tephra; C. Hekla tephra AD 1158; D. Öræfajökull tephra AD 1362; E. Hekla tephra AD 1510; F. Eyjafjallajökull AD 1821-1823 tephra; G. Askja tephra AD $1875 .+=$ data from a tephra zone $13-16 \mathrm{~cm}$ below the surface at Loch Portain, North Uist, in the Outer Hebrides of Scotland (NGR 950724) (data from Dugmore, Larsen and Newton 1995; Larsen et al.). The geochemical correlation between the Loch Portain tephra and tephra from the AD 1510 eruption of Hekla in Iceland agrees with the ${ }^{14} \mathrm{C}$ dating of the Scottish profile (cf. Fig. 1).

Although limited, the ages of tephra layers based on the routine ${ }^{14} \mathrm{C}$ dating of single profiles provide chronological control useful for a wide range of paleoenvironmental applications. The Glen Garry tephra, found at sites across Scotland, was first dated in Caithness to $2120 \pm 60 \mathrm{BP}$ (GU-7017). This is supported by a ${ }^{14} \mathrm{C}$ age of $2010 \pm 60 \mathrm{BP}$ (GU-7016) above the tephra and $2220 \pm 80 \mathrm{BP}$ (GU-7018) below it. Subsequently, this dating has been further supported by ${ }^{14} \mathrm{C}$ dating on a peat profile containing the Glen Garry tephra at Achany Glen, Sutherland (NGR NC 020583) (M. Smith, written communication). The age attributed to the Glen Garry tephra is, at present, no more precise than other dates routinely determined for Holocene paleoenvironmental studies, but it is noteworthy because it may be applied, and further refined whereever the tephra is identified; currently, this includes $>27,000 \mathrm{~km}^{2}$ of northern Scotland and part of southeastern Iceland (Dugmore and Newton 1992; Dugmore, Larsen and Newton 1995; Larsen, Newton and Dugmore, ms.). Given the large areas covered by Icelandic tephras, both in Iceland and abroad, and the extensive range of applications for tephrochronology in paleoenvironmental studies, precise and accurate ages of tephra layers would be most useful. In proximal areas where tephra form visible layers, the relative dating preci- 
sion is frequently to $<1 \mathrm{yr}$ because it is possible to identify the surface onto which the tephra fell. ${ }^{14} \mathrm{C}$ dating will never be able to match such a level of precision, but there is significant room for improvement, especially in the British Isles and Scandinavia, where tephra deposits are fine grained and form invisible horizons. In the British Isles, a clear target is to reduce the gap between the $c a$. 250 -yr range for the most probable age of tephras, as determined by routine ${ }^{14} \mathrm{C}$ dating, and the 40 to 80 -yr range for the relative dating precision commonly achievable in Holocene blanket peats, based on typical rates of accumulation and the stratigraphic spread of the tephra (Barber 1981; Dugmore and Newton 1992; Pilcher and Hall 1992). One strategy for improving dating precision is the high-precision multisample technique, or "wiggle-matching".

\section{High-Precision Multisample ${ }^{14} \mathrm{C}$ Dating, or "Wiggle-Matching”}

A profile of high-precision ${ }^{14} \mathrm{C}$ dates through rapidly accumulating peats, such as those found in the lowland raised bogs of Northern Ireland, may be matched against the calibration curve to produce very precise age estimates. This strategy has been used by Pilcher, Hall and McCormac $(1994,1995)$ to produce dates of $\mathrm{AD} 1088 \pm 20$ and $860 \pm 20$ for two tephras in Northern Ireland. In these dates, an uncertainty of $<10 \mathrm{yr}$ is attributable to the fit to the calibration curve. The final uncertainty was increased to \pm 20 to cover possible variation in peat accumulation rates. This provision is needed to produce an age range of $\mathrm{AD} 1068-1108$, which is wide enough to be consistent with the correlation of the younger tephra to the AD 1104 eruption of Hekla on the basis of its geochemical characteristics. It would therefore seem probable that variation in peat accumulation rates introduces some bias to the high-precision multisample age estimates for tephras of historical age.

Similar uncertainties are likely when using ${ }^{14} \mathrm{C}$ "wiggle-matching" with older tephras, and this provision is included in the dating of $2310 \pm 20 \mathrm{BC}$ for a deposit of the Hekla 4 tephra at Sluggan Bog in Northern Ireland (Fig. 3; Hall, Pilcher and McCormac 1994; Pilcher, Hall and McCormac 1994, 1995). However, variation in peat growth around the Hekla 4 tephra may be somewhat greater than that above and below the tephras of historical age considered earlier. A phase of reduced growth lasting $15 \mathrm{yr}$ began at $2350 \mathrm{BC}$ in oaks growing at Garry Bog and sites south of Lough Neagh in Northern Ireland (Baillie and Munro 1988). Although there are no palynological changes around the Hekla 4 tephra at Sluggan Bog comparable with those observed in Caithness, Scotland the tree-ring data show that short-lived but significant environmental changes were occurring at about or just before this time in the lowland raised bogs of Northern Ireland (Figs. 3 and 4; Blackford et al. 1992; Hall, Pilcher and McCormac 1994). This raises the possibility that variation in the rate of peat accumulation may occur in close association with some prehistoric tephras, which is significantly greater than that associated with recent deposits. This factor may reduce the high precision potentially achievable by ${ }^{14} \mathrm{C}$ "wiggle-matching" with peat sequences. As only a restricted number of Icelandic tephras are present in the Irish peats most suitable for "wiggle-matching", alternatives must be used to improve the resolution of the ${ }^{14} \mathrm{C}$ dating of other key tephras.

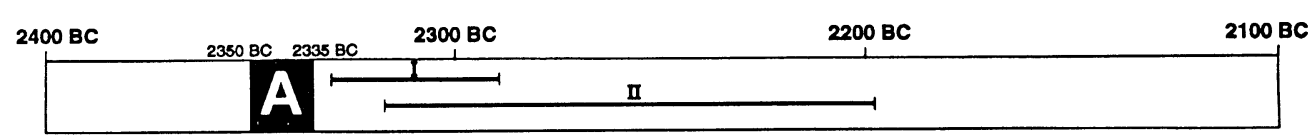

Fig. 3. Calibrated age estimates for the Hekla 4 tephra and the age of a growth downturn in the Irish tree-ring record (Baillie and Munro 1988). "Wiggle matching" has yielded a date of $2310 \pm 20 \mathrm{BC}$ for Hekla 4 tephra (Hall, Pilcher and McCormac 1994), shown as age range I. We report a compilation of dates that produced a ${ }^{14} \mathrm{C}$ age of $3832 \pm 12 \mathrm{BP}$ or a calibrated age range $2317-2198 \mathrm{BC}$, which is shown as age range II. Both age ranges are younger than the growth downturn in the tree-ring record that dates to between 2350 and $2335 \mathrm{BC}$ (area A). These data suggest that a short-lived environmental change that significantly affected oak tree growth in areas close to peats bogs occurred before the deposition of the Hekla 4 tephra and could have also affected peat accumulation rates. 


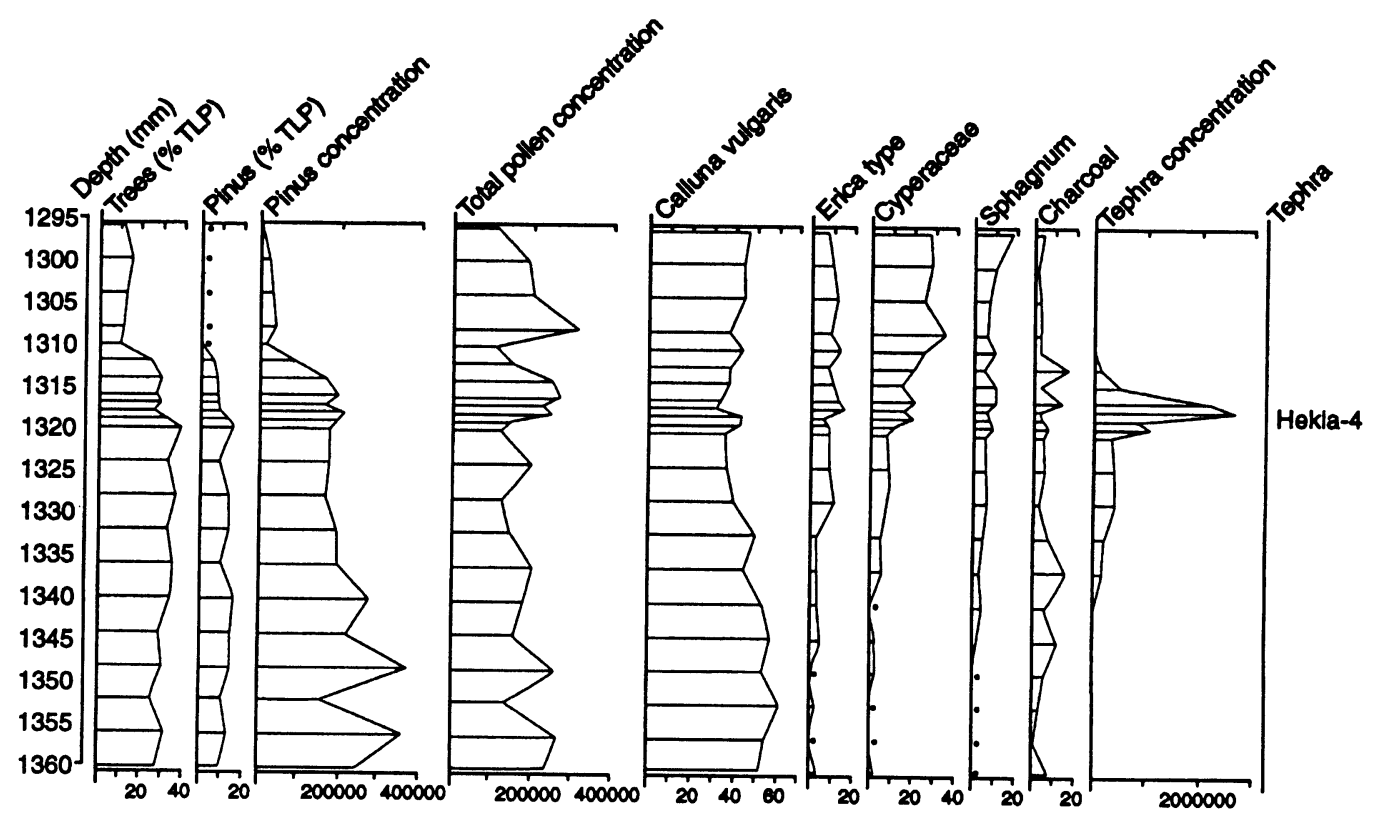

Fig. 4. High-resolution, millimeter-scale pollen, charcoal and tephra data from Loch Leir in Caithness from Blackford et al. (1992) show a stratigraphic link between the decline of Pinus sylvestris pollen and the deposition of the Hekla 4 tephra. The implication is that significant ecological changes occurred in this area of Scotland at about the time of the deposition of the tephra.

\section{A Spatial Compilation of ${ }^{14} \mathrm{C}$ Dates}

Another approach to improving the precision of ${ }^{14} \mathrm{C}$ ages for tephra layers is to combine separate dates (e.g., Vogel et al. 1990). In Icelandic peats, the surface layers covering a tephra fall may be identified, and a more precise ${ }^{14} \mathrm{C}$ age on the deposition of the tephra may be obtained by combining results on chronologically equivalent material from different sites. An advantage to this method is that it may be applied in proximal areas where a tephra layer may be disturbed, effectively ruling out the "wiggle-matching" approach used in Ireland. Any site-specific bias may also be greatly reduced, and dating precision closer to that of the stratigraphic resolution of the tephra isochrone may be achieved with a routine series of ${ }^{14} \mathrm{C}$ dates.

Dating Icelandic tephras in proximal areas is important because they form visible layers in continuous vertical sequences containing up to 80 other tephras (Fig. 5). Detailed mapping of tephra layers in Iceland has produced accurate information about the stratigraphic relation between different tephras (e.g., Thórarinsson 1967; Larsen 1982, 1984; Dugmore 1987). As more dating evidence becomes available, this framework becomes tighter, forming a tephrochronology that is much stronger than simply the sum of the separately dated layers. Whatever the uncertainties about the dating on individual tephras, the sequence of events is known.

Close to the source areas, stratigraphical relations can be used to distinguish clearly between tephras formed by separate eruptions. Different tephras produced by the same volcanic system can have similar geochemical characteristics (Jakobsson 1979; Imsland 1978; Larsen 1981, 1982). Subsequently, the geochemical data may be applied in distal areas where tephra deposits are less numerous and microscopic, and can present significant analytical challenges due to their small grain size, vesicularity and potential instability during electron probe microanalysis (Larsen 1981; Hunt and 
Hill 1993). Without rigorous linkage to the source areas, different tephras from the same volcanic system may be identified mistakenly as the product of a single eruption. Effective correlation between tephra studies in proximal and distal areas is essential, particularly if chronological data from one specific area is to be applied throughout the range of the tephra distribution.

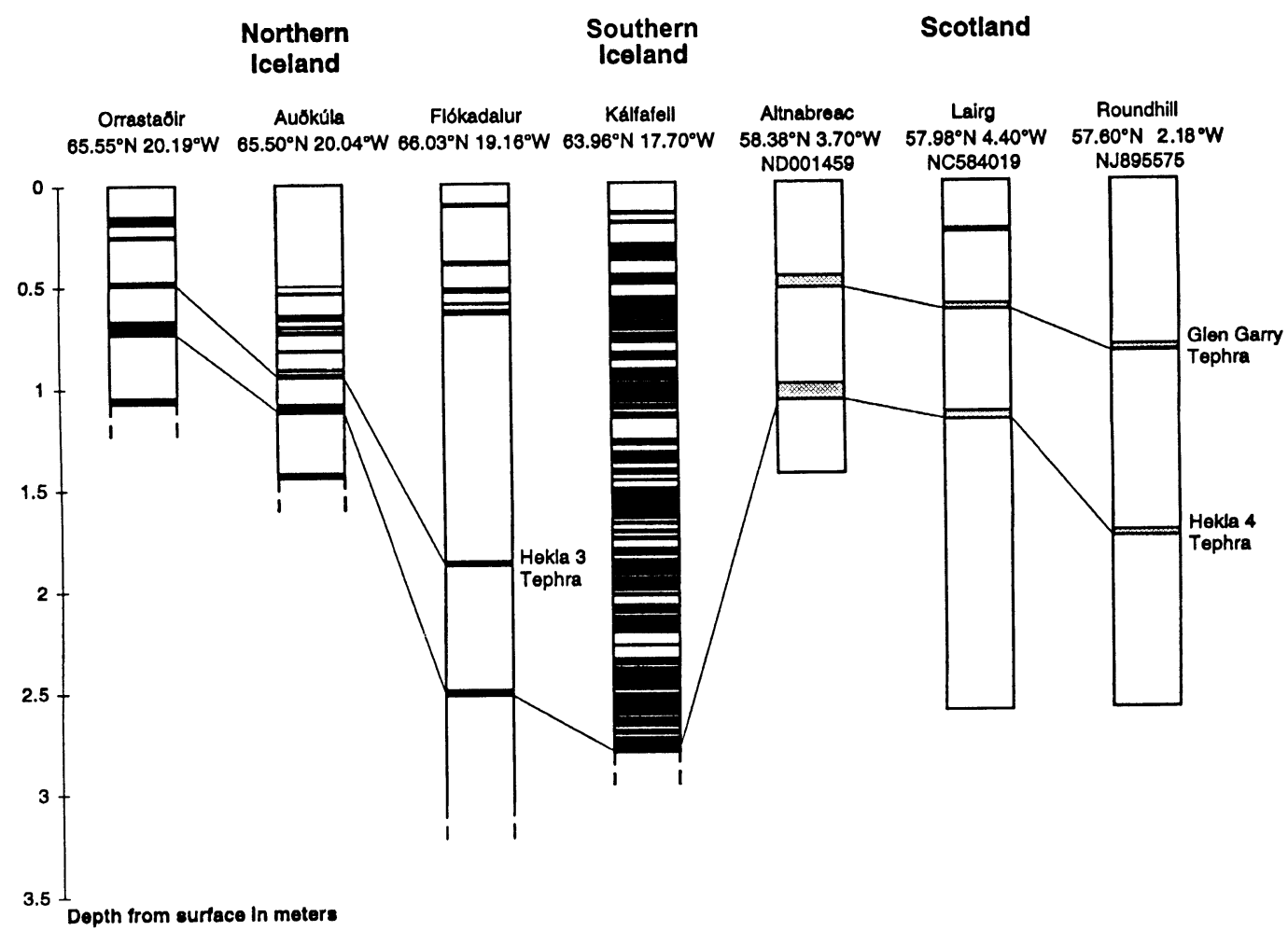

Fig. 5. Stratigraphic sections including the Hekla 3, Glen Garry and Hekla 4 tephras. - = visible tephra layers in Iceland. In Scotland, where the grains of tephra are $<150 \mu \mathrm{m}$ and the mass loading $<10$ tonnes ha ${ }^{-1}$, the deposits are invisible ( Peak grain abundance occurs over more restricted depths than the distribution of the tephra horizon as a whole (cf. Fig. 4). Tephra layers are most abundant in southern Iceland where peat accumulation rates are affected by the frequent mantling of the bog surface with inorganic material. For clarity, the identification of other tephra layers has been omitted.

The Hekla 4 tephra has been identified at many sites in Iceland and the British Isles, seven of which are shown in Figure 5. Geochemical analysis has been used at each site to determine the identity of the tephra permitting accurate correlation between sites $1200 \mathrm{~km}$ apart (Fig. 6). Combined ${ }^{14} \mathrm{C}$ dates from 15 profiles at these sites give $3826 \pm 12$ BP for Hekla 4 (Table 1; Pearson and Stuiver 1993). In Iceland, we took peat samples below the tephra layer because the surface onto which the tephra had fallen was clearly identifiable. In contrast, the overlying peat did not always begin to form immediately after the eruption. In some profiles, tephra layers formed soon after $3800 \mathrm{BP}$ are either missing, or mixed together with a reworked upper part of the Hekla 4 tephra. In Scotland, as the surface onto which the tephra had fallen could not be seen, we used slices of peat that enclosed the level of peak tephra-grain abundance.

Hekla 3 has attracted considerable attention as it erupted at about the same time as several other events, which include a brief and unusual period of growth downturn in the Irish dendrochronolog- 
TABLE $1 .{ }^{14} \mathrm{C}$ ages obtained for peat underlying $(0-2 \mathrm{~cm})$ Hekla 4 tephra at Orrastaðir $\left(65.55^{\circ} \mathrm{N}, 20.19^{\circ} \mathrm{W}\right)$, Flókadalur $\left(66.03^{\circ} \mathrm{N}, 19.16^{\circ} \mathrm{W}\right)$ and Aứkúla $\left(65.50^{\circ} \mathrm{N}\right.$, $\left.20.04^{\circ} \mathrm{W}\right)$, Iceland, and Altnabreac $\left(58.38^{\circ} \mathrm{N}, 3.70^{\circ} \mathrm{W}\right)$, Lairg $\left(57.98^{\circ} \mathrm{N}, 4.40^{\circ} \mathrm{W}\right)$ and Roundhill $\left(57.60^{\circ} \mathrm{N}, 2.18^{\circ} \mathrm{W}\right)$, Scotland. The tephra stratigraphy for each site is shown in Figure 5. Calibration is after Stuiver and Reimer (1993).

\begin{tabular}{|c|c|c|c|c|c|}
\hline Lab no. & $\begin{array}{l}\text { Fraction } \\
\text { dated }\end{array}$ & Site & $\begin{array}{c}\text { Age } \\
\text { (yr BP) }\end{array}$ & $\begin{array}{l}\delta^{13} \mathrm{C} \\
(\% 0)\end{array}$ & $\begin{array}{l}\text { Cal range } \\
\text { BC }(2 \sigma)\end{array}$ \\
\hline \multicolumn{6}{|c|}{ Hekla 4 tephra (Iceland) } \\
\hline GU-7001 & Humic acid & Orrastað̌ir & $3890 \pm 90$ & -29.6 & $2582-2044$ \\
\hline GU-7010a & Humic acid & Orrastaðir & $3910 \pm 80$ & -29.7 & $2582-2139$ \\
\hline GU-7010b & Humin & Orrastaðir & $3680 \pm 170$ & -29.6 & $2558-1618$ \\
\hline GU-3240 & Humic acid & Orrastaరir & $3850 \pm 50$ & -29.1 & 2462-2139 \\
\hline GU-3241 & Humic acid & Orrastaðir & $3790 \pm 50$ & -28.6 & 2398-2037 \\
\hline GU-3242 & Humic acid & Orrastaðir & $3790 \pm 50$ & -28.9 & $2398-2037$ \\
\hline GU-3243 & Humic acid & Orrastaðir & $3820 \pm 50$ & -28.9 & $2455-2047$ \\
\hline GU-4334 & Humic acid & Orrastaðir & $3820 \pm 50$ & -29.3 & $2455-2047$ \\
\hline GU-4335 & Humin & Orrastaðir & $3770 \pm 50$ & -29.2 & $2330-1988$ \\
\hline GU-4336 & Humic acid & Orrastaðir & $3750 \pm 50$ & -29.0 & $2290-1980$ \\
\hline GU-4337 & Humin & Orrastaðir & $3750 \pm 50$ & -28.9 & $2290-1980$ \\
\hline GU-7011 & Humic acid & Aưokúla & $4020 \pm 80$ & -28.4 & $2869-2312$ \\
\hline GU-7022 & Humic acid & Aưokúla & $3820 \pm 50$ & -28.5 & 2455-2047 \\
\hline GU-7023 & Humin & Auðkúla & $3910 \pm 100$ & -28.4 & 2837-2044 \\
\hline GU-7024 & Humic acid & Aưokúla & $3930 \pm 60$ & -28.6 & $2573-2203$ \\
\hline GU-7025 & Humin & Auð̌kúla & $3730 \pm 90$ & -28.6 & $2453-1884$ \\
\hline GU-7051 & Humic acid & Auð̌kúla & $3940 \pm 50$ & -28.2 & $2569-2283$ \\
\hline GU-7052 & Humin & Auð̌kúla & $3700 \pm 360$ & -28.7 & 3036-1204 \\
\hline GU-7053 & Humic acid & Auơkúla & $3760 \pm 50$ & -28.0 & 2319-1984 \\
\hline GU-7054 & Humin & Auơkúla & $3740 \pm 80$ & -28.1 & $2451-1907$ \\
\hline GU-7122 & Humic acid & Aưokúla & $3800 \pm 50$ & -27.9 & $2451-2041$ \\
\hline GU-7123 & Humic acid & Aưokúla & $3860 \pm 50$ & -27.8 & 2464-2142 \\
\hline GU-7128 & Humic acid & Flókadalur & $3880 \pm 50$ & $\mathrm{n} / \mathrm{a}^{*}$ & 2469-2147 \\
\hline GU-7129 & Humin & Flókadalur & $3890 \pm 60$ & -27.2 & 2554-2145 \\
\hline GU-7130 & Humic acid & Flókadalur & $3860 \pm 50$ & -28.8 & $2464-2142$ \\
\hline GU-7131 & Humin & Flókadalur & $3870 \pm 60$ & -27.0 & $2476-2139$ \\
\hline GU-3017 & Humic acid & Kálfafell & $3880 \pm 70$ & -27.9 & $2559-2137$ \\
\hline GU-3018 & Humic acid & Kálfafell & $3840 \pm 50$ & -27.9 & $2460-2136$ \\
\hline \multicolumn{6}{|c|}{ Hekla 4 Tephra (UK) } \\
\hline GU-3012 & Humic acid & Altnabreac & $3880 \pm 70$ & -28.5 & $2559-2137$ \\
\hline GU-7102 & Humic acid & Lairg & $3680 \pm 50$ & -29.4 & 2194-1904 \\
\hline GU-7103 & Humin & Lairg & $3790 \pm 50$ & -28.9 & $2398-2037$ \\
\hline GU-7104 & Humic acid & Lairg & $3740 \pm 50$ & -29.5 & 2286-1975 \\
\hline GU-7105 & Humin & Lairg & $3890 \pm 50$ & -27.3 & 2477-2196 \\
\hline GU-3819 & Humic acid & Lairg & $3870 \pm 50$ & -29.6 & $2467-2144$ \\
\hline GU-3218 & Humic acid & Roundhill & $3800 \pm 100$ & -28.4 & 2489-1934 \\
\hline
\end{tabular}


ical record, an acidity peak in Greenland ice and putative archaeological change in the British Isles (Burgess 1989; Baillie 1989a,b; but $c f$. Buckland, Dugmore and Edwards, ms.). The Hekla 3 tephra has been dated in six profiles at Flókadalur and Aurkúla in northern Iceland (Fig. 5). The weighted mean for these dates is $2879 \pm 34 \mathrm{BP}$ (Table 2).

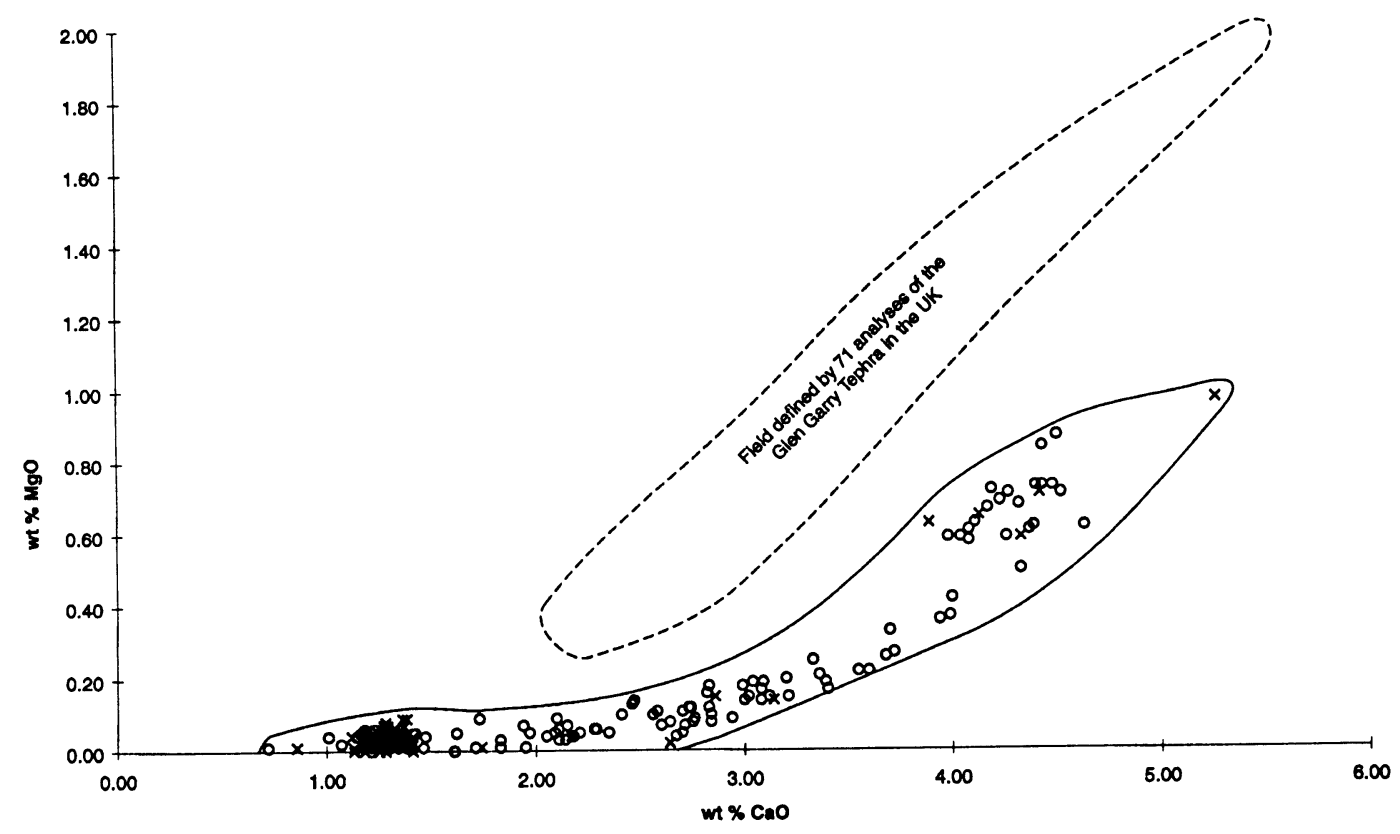

Fig. 6. Geochemical characteristics of the Hekla 4 tephra (-), and Glen Garry tephra (---) at the ${ }^{14} \mathrm{C}$-dated sites considered in this paper ( $c f$. Fig. 5). The separation of the two fields illustrates the discrimination of different tephras possible through the use of geochemical analysis. Points within the field for Hekla 4 represent the analyses of individual grains in Iceland $(x)$ and Scotland (o) and illustrate effective correlation between areas up to $1200 \mathrm{~km}$ apart (Dugmore et al. 1992). The range of values represent changes during the course of the eruption, and show that all of the silicic parts of the tephra present in southern Iceland also occur in Scotland (Larsen and Thórarinsson 1977; Dugmore, Larsen and Newton 1995).

TABLE $2 .{ }^{14} \mathrm{C}$ ages obtained for peat underlying $(0-2 \mathrm{~cm})$ Hekla 3 tephra at Flókadalur $\left(66.03^{\circ} \mathrm{N}, 19.16^{\circ} \mathrm{W}\right)$ and Aurkúla $\left(65.50^{\circ} \mathrm{N}, 20.04^{\circ} \mathrm{W}\right)$, Iceland. The tephra stratigraphy for both sites is shown in Figure 5. Calibration is after Stuiver and Reimer (1993).

\begin{tabular}{lllccc}
\hline Lab no. & $\begin{array}{l}\text { Fraction } \\
\text { dated }\end{array}$ & Site & $\begin{array}{c}\text { Age } \\
\text { (yr BP) }\end{array}$ & $\begin{array}{c}\delta^{13} \mathrm{C} \\
(\%)\end{array}$ & $\begin{array}{c}\text { Cal range } \\
\text { BC }(2 \text { \%) }\end{array}$ \\
\hline GU-7028 & Humic acid & Flókadalur & $2960 \pm 50$ & -29.2 & $1372-1003$ \\
GU-7029 & Humin & Flókadalur & $2840 \pm 100$ & -29.1 & $1297-805$ \\
GU-7030 & Humic acid & Auðkúla & $2820 \pm 50$ & n/a* & $1117-836$ \\
GU-7031 & Humin & Auðkúla & $2810 \pm 80$ & -29.0 & $1198-807$ \\
GU-7032 & Humic acid & Auðkúla & $3060 \pm 50$ & -28.6 & $1421-1133$ \\
GU-7036 & Humic acid & Auðkúla & $2910 \pm 50$ & -28.6 & $1260-925$ \\
GU-7037 & Humin & Auðkúla & $2750 \pm 80$ & -29.2 & $1113-794$ \\
GU-7038 & Humic acid & Auðkúla & $2800 \pm 50$ & -28.7 & $1047-826$ \\
GU-7039 & Humin & Auðkúla & $2810 \pm 50$ & -28.9 & $1113-830$ \\
\hline
\end{tabular}

*n/a $=$ not analyzed 
These dates offer a precision that narrows the gap between the resolution of the ${ }^{14} \mathrm{C}$ ages and the precision of stratigraphic correlation possible with tephra layers, and illustrates an approach that can be used with virtually all the Icelandic tephra formed during the postglacial period. ${ }^{14} \mathrm{C}$ dating tephra layers also allows one to compare groups of results for thematic or spatial categories, and for different peat fractions, types of vegetation and areas as far apart as northern Iceland and the Scottish Highlands (Shore, Cook and Dugmore 1995). The greatest possible precision is always desirable, but as a compromise between the considerations of cost, the need for widespread applicability to Icelandic tephra stratigraphy and the production of absolute dates of a good resolution, the combination of chronologically equivalent dates is an effective approach.

\section{Conclusion}

1. Effective dates on tephra layers can be determined by ${ }^{14} \mathrm{C}$ analyses on a single profile, but precision can be significantly increased by combining analyses from several sites.

2. A dating strategy based on multiple analyses of samples of the same age underlying a tephra layer also presents an opportunity to evaluate site-specific factors that may influence ${ }^{14} \mathrm{C}$ con-
tent.

3. High-precision multisample ${ }^{14} \mathrm{C}$ dating techniques, or "wiggle-matching", can produce particularly accurate and precise age determinations at appropriate sites, but this approach may be applied only to a few Icelandic tephra layers.

4. The correct identification of tephra is critical, and of particular concern with Icelandic material is the possibility that different tephra from the same volcanic system may be mistakenly identified as the product of a single eruption.

\section{ACKNOWLEDGMENTS}

We gratefully acknowledge financial support from the Leverhulme Trust, the UK Natural Environment Research Council and the Carnegie Trust for the Universities of Scotland. Electron probe microanalyses were undertaken at the Department of Geology and Geophysics, University of Edinburgh with the support of Peter Hill and Stuart Kearns. Permission to undertake parts of this research in Iceland was granted by the Icelandic Council for Science.

\section{REFERENCES}

Baillie, M. L. 1989a Do Irish bog oaks date the Shang Dynasty? Current Archaeology 117: 301-310.

1989b Hekla 3- just how big was it? Endeavour 13(2): 78-81.

Baillie, M. L. and Munro, M.A.R. 1988 Irish tree rings; Santorini and volcanic dust veils. Nature 332: 344 346.

Barber, K. E. 1981 Peat Stratigraphy and Climatic Change, Balkema, Rotterdam.

Bennett, K. D., Boreham, S., Sharp, M.J. and Switsur, V. R. 1992 Holocene history of environment, vegetation and human settlement on Catta Ness, Lunnasting, Shetland. Journal of Ecology 80: 241-273.

Björk, S., Ingólfsson, O., Hafliðason, H., Hallsdóttir, M. and Anderson N. J. 1992 Lake Torfadalsvatn: A high resolution record of the North Atlantic ash zone I and the last glacial-interglacial environmental changes in Iceland. Boreas 21: 15-22.
Blackford, J. J., Edwards, K. J., Dugmore, A. J., Cook, G. T. and Buckland, P. C. 1992 Icelandic volcanic ash and the mid-Holocene Scots pine (Pinus sylvestris) pollen decline in northern Scotland. The Holocene 2: 260265.

Buckland, P. C., Dugmore, A. J. and Edwards, K. J. (ms.) Volcanic activity and human response in the Mediterranean and the North Atlantic region. Quaternary Science Reviews, in press.

Burgess, C. 1989 Volcanoes, catastrophe and global crisis of the late 2nd millennium BC. Current Archaeology 117: 325-329.

Dugmore, A. J. 1987 (ms.) Holocene Glacial Fluctuations Around Eyjafjallajökull, South Iceland. Ph.D. dissertation, University of Aberdeen: $214 \mathrm{p}$. 1989 Tephrochronological studies of Holocene glacier fluctuations in southern Iceland. In Oerlemans, J., ed., Glacier Fluctuations and Glacial Change, Dor- 
drecht, Kluwer Academic Publishers: 37-55.

Dugmore, A. J., Larsen, G., and Newton, A. J. 1995 Seven tephra isochrones in Scotland. The Holocene 5(3): 257-266.

Dugmore, A. J., Larsen, G., Newton, A. J. and Sugden, D. E. 1992 Geochemical stability of fine-grained silicic tephra layers in Iceland and Scotland. Journal of Quaternary Science 7: 173-183.

Dugmore, A. J and Newton, A. J. 1992 Thin tephra layers in peat revealed by X-radiography. Journal of Archaeological Science 19: 163-170.

Edwards, K. J., Buckland, P. C., Blackford, J. J., Dugmore, A. J. and Sadler, J. P. 1994 The impact of tephra: Proximal and distal studies of Icelandic eruptions. Muncher Geographische Auhandlungen B12: 79101.

Hall, V. A., Pilcher, J. R. and McCormac, F. G. 1994 Icelandic volcanic ash and the mid-Holocene Scots pine (Pinus sylvestris) decline in the north of Ireland: No correlation. The Holocene 41: 79-83.

Hallsdóttir, M. 1987 Pollen analytical studies of human influence on vegetation in relation to the. Landnám tephra layer in southwestern Iceland. Lundqua Thesis 18: $1-45$.

Hunt, J. and Hill, P.G. 1993 Tephra geochemistry: a discussion of some persistent analytical problems. The Holocene 3: 271-278.

Imsland, P. 1978 Petrology of Iceland; some general remarks. Nordic Volcanological Institute Reports 7808: 1-19.

Jakobsson, S. P. 1979 Petrology of recent basalts of the Eastern Volcanic Zone, Iceland. Acta Naturalia Islandica 26: 1-103.

Kjartansson, G., Thórarinsson, S. and Einarsson, Th. $1964{ }^{14} \mathrm{C}$ dating of Quaternary deposits in Iceland. Natturufraedingurinn 34: 97-145.

Larsen, G. 1981 Tephrochronology by microprobe glass analysis. In Self, S. and Sparks, R. S. J., eds., Tephra Studies, Dordrecht, Reidel: 95-102. 1982 Gjóskutímatal Jökuldals og nágrennis (Tephrochronology of Jokuldalur and the surrounding areas). In Thorarindóttir H., Öskarsson, Ó. H., Steinthórsson, S. and Einarsson, Th., eds., Eldur er $t$ Norठri. Sógufelag, Reykjavik: 51-66.

1984 Recent volcanic history of the VeiOivötn fis- sure swarm, southern Iceland - An approach to volcanic risk assessment. Journal of Volcanology and Geothermal Research 22: 33-58.

Larsen, G., Newton, A. J. and Dugmore, A. J. The Suinafell tephra reference profile in southeast Iceland. Unpublished manuscript.

Larsen, G. and Thórarinsson, S. $1977 \mathrm{H} 4$ and other acidic Hekla tephra layers. Jökull 27: 28-46.

Merkt, J., Muller, H., Knabe, W., Muller, P. and Weiser, T. 1993 The early Holocene Saksunarvatn Tephra found in lake sediments in N.W. Germany. Boreas 22: 93-100.

Ogilvie, A. E. J. 1984 The past climate and sea-ice record from Iceland, Part 1: Data to $\mathrm{AD}$ 1780. Climate Change 6: 131-152.

Pearson, G.W. and Stuiver, M. 1993 High-precision bidecadal calibration of the radiocarbon time scale 500-2500 BC. In Stuiver, M., Long, A. and Kra, R. S., eds., Calibration 1993. Radiocarbon 35(1): 25-33.

Pilcher, J. R., and Hall, V. A. 1992 Towards a tephrochronology for the Holocene of the north of Ireland. The Holocene 2: 255-259.

Pilcher, J. R., Hall, V. A. and McCormac, F. G. 1994 Dating tephra layers in peats by high precision multi-sample technique. (Abstract) 15th International Radiocarbon Conference, Glasgow, Scotland, 15-19 August.

1995 Dates of Holocene eruptions from tephra layers in Irish peats. The Holocene 5: 103-110.

Shore, J. S., Cook, G. T. and Dugmore A. J. 1995 The ${ }^{14} \mathrm{C}$ content of modern vegetation samples from the flanks of the Katla volcano, southern Iceland. Radiocarbon, this issue.

Stuiver, M. and Reimer, P. J. 1993 Extended ${ }^{14} \mathrm{C}$ data base and revised CALIB $3.0{ }^{14} \mathrm{C}$ age calibration program. In Stuiver, M., Long, A. and Kra, R. S., eds., Calibration 1993. Radiocarbon 35(1): 215-230.

Thorarinsson, S. 1967 The eruption of Hekla in historical times. The eruption of Hekla 1947-1948 1: 1-170.

1981 Greetings from Iceland - Ash-falls and volcanic aerosols in Scandinavia. Geografiska Annaler Series A 633-4: 109-110.

Vogel, J. S., Cornell, W., Nelson, D. E. and Southon, J. R. 1990 Vesuvius/Avellino, one possible source of seventeenth century BC climatic disturbances. Nature 344: 534-537. 